\title{
Pre-breeding blood urea nitrogen concentration and reproductive performance of Bonsmara heifers within different management systems
}

\author{
T. Tshuma ${ }^{\text {a }}$ D. E. Holm ${ }^{\mathrm{a}}$; G. T. Fosgate ${ }^{\mathrm{a}}$; D. C. Lourens ${ }^{\mathrm{a}}$ \\ ${ }^{a}$ Department of Production Animal Studies, Faculty of Veterinary Science, University of Pretoria, Private Bag X \\ 04, Onderstepoort, 0110, South Africa
}

Corresponding author: Takula Tshuma, BVSc, MMedVet (Bov HH)

Email: takula.tshuma@up.ac.za

Tel: $+27-12-529-8039$

Fax: +27- 12-529 8315

\begin{abstract}
This study investigated the association between pre-breeding blood urea nitrogen (BUN) concentration and reproductive performance of beef heifers within different management systems in South Africa. Bonsmara heifers $(n=369)$ from five herds with different estimated levels of nitrogen intake during the month prior to the commencement of the breeding season were sampled in November and December 2010 to determine BUN concentrations. Body mass, age, body condition score (BCS) and reproductive tract score (RTS) were recorded at study enrolment. Trans-rectal ultrasound and/or-palpation was performed four to eight weeks after a three-month breeding season to estimate the stage of pregnancy. Days to pregnancy (DTP) was defined as the number of days from the start of the breeding season until the estimated conception date. Logistic regression and Cox proportional hazards survival analysis were performed to estimate the association of pre-breeding BUN concentration with subsequent pregnancy and DTP respectively. After stratifying for herd and adjusting for age,
\end{abstract}


heifers with relatively higher pre-breeding BUN concentration took longer to become pregnant when compared to those with relatively lower BUN concentration $(P=0.011)$. In the herd with the highest estimated nitrogen intake $(n=143)$, heifers with relatively higher BUN were less likely to become pregnant $(P=0.013)$ and if they did, it was only later during the breeding season $(P=0.017)$, after adjusting for body mass. These associations were not present in the herd $(\mathrm{n}=106)$ with the lowest estimated nitrogen intake $(P>0.500)$. It is concluded that Bonsmara heifers with relatively higher pre-breeding BUN concentration, might be at a disadvantage because of this negative impact on reproductive performance, particularly when the production system includes high levels of nitrogen intake.

\section{Keywords}

beef cattle, blood urea nitrogen, reproductive performance, nitrogen supplementation

\section{Introduction}

Ruminants are capable of maintaining adequate nitrogen levels for microbial protein synthesis in the rumen even during times of nitrogen scarcity, mainly by recycling nitrogen back into the rumen and by reducing the amount excreted into urine, faeces and milk (Erickson and Klopfenstein, 2010, Dijkstra et al., 2011). However the limits of this physiological adaptation are still unknown (Muscher et al., 2010). The efficiency of nitrogen retention in feedlot cattle is low, with only 10 to $15 \%$ of dietary nitrogen retained in tissues (Bierman et al., 1999) and the remainder being excreted. However, lower proportions may be excreted by cattle in extensive production systems where the level of nitrogen intake is relatively lower.

Blood urea nitrogen (BUN) is the major end product of nitrogen metabolism in ruminants. It has been suggested in dairy cattle that BUN concentration can be used to monitor the 
efficiency of nitrogen utilisation, where high concentrations are indicative of inefficient utilisation of dietary nitrogen (Nousiainen et al., 2004). This is however contrary to Schoeman's (1989) review, who suggested that Nguni cattle with higher BUN concentrations were more capable of maintaining body condition during winter periods, suggesting that they were more efficient retainers of nitrogen. Although the study of Kohn et al. (2005) demonstrated a linear relationship between BUN concentration and urinary nitrogen excretion rate in many species, the exact association between relative BUN concentration and the efficiency of nitrogen retention in grazing beef cattle remains unclear.

Blood urea nitrogen is synthesized in the liver, and can have variable concentrations without causing any adverse effects to the fertility of cattle. However, concentrations above $20 \mathrm{mg} / \mathrm{dL}$ at the time of breeding may lead to reduced fertility in dairy cattle (Ferguson et al., 1993). Elevated BUN concentration decreases uterine $\mathrm{pH}$, which is thought to have a negative effect on embryo development and implantation (Elrod and Butler, 1993). It has been suggested, however, that the negative association between high BUN concentration and reproductive outcome might be confounded by a concurrent energy deficit (Staples et al., 1990). Blood urea nitrogen concentrations below $7 \mathrm{mg} / \mathrm{dL}$ at breeding have been reported to also be associated with reduced reproductive performance due to protein deficiency (Carlsson and Pehrson, 1993). In their review Jorritsma et al. (2003) concluded that the effects of urea on fertility are likely to occur during cleavage and blastocyst formation of the fertilised embryo, whereas the effects of high levels of ammonia in the blood are probably exerted prior to ovulation. It is estimated that follicles start to develop about 100 days prior to ovulation (Britt, 2008).

Blood urea nitrogen concentration, and hence the efficiency of nitrogen retention is believed to vary between and within cattle breeds (Schoeman, 1989; Chase Jr. et al., 1993). Several studies have also reported genetic variation in milk urea nitrogen (MUN) concentration 
(indirect indication of BUN concentration) between cows of the same breed, suggesting genetic differences in nitrogen utilisation efficiency (Stoop et al., 2007; Bouwman et al., 2010; Hossein-Zadeh and Ardalan, 2011). Possible reasons for this variation include differing grazing habits or differences in the rate of urea excretion by the kidneys (Schoeman, 1989). Other known sources of variation in BUN concentration are dietary protein and energy levels, hydration status at time of sampling, time of sample collection, age of the animal, dry matter intake and the particular method of analysis (Godden et al., 2001; Kauffman and St-Pierre, 2001; Rajala-Schultz and Saville, 2003; Hossein-Zadeh and Ardalan, 2011). Mitchell et al. (2005) demonstrated that variation in MUN is genetically determined and has a heritability of 0.15. The objective of this study was to determine if the relative BUN concentration within a herd was associated with reduced reproductive performance in Bonsmara heifers within different management systems.

\section{Materials and Methods}

Study locality and study herds

Nulliparous Bonsmara heifers $(n=369)$ were enrolled from 5 herds in South Africa (Herds A-E according to sampling order). Herds that met study criteria (practised a 3-month restricted breeding program starting on the first of December, performed a veterinary breeding soundness evaluation of bulls before the onset of the breeding season and kept records on birth dates and body mass of their animals) were identified by convenience sampling. All herds were located between the latitudes $23^{\circ} 21^{\prime} 53^{\prime \prime}$ and $27^{\circ} 29^{\prime} 9^{\prime \prime}$ South. Herds A, C and D were managed on sourish mixed bushveld in the Limpopo Province. Herd B was managed on sweet mixed bushveld in the Limpopo Province whereas Herd E was managed on sour veld in the Free State Province. In all herds, lick supplements were delivered in feed 
troughs onto the pasture and intake was estimated according to the manufacturer's recommendations.

Herds $\mathrm{A}$ and $\mathrm{C}$ were commercial cow-calf herds whereas $\mathrm{B}, \mathrm{D}$ and $\mathrm{E}$ were registered breeding herds. All herds practised a three-month restricted breeding program starting on the first of December each year. Breeding bulls were determined to be breeding sound prior to the breeding season as described by Irons et al. (2007). Facilities on the farms did not allow heifers to have access to feed while in the holding pens and access to drinking water was only available for Herds A, B and D.

Heifers in Herd A were bred by four bulls in one multisire group. These heifers were managed extensively on pasture and received a $46 \%$ crude protein $(\mathrm{CP})$ commercial protein lick supplement (Protein lick with oil cake, KK Animal Nutrition, South Africa). The recommended daily intake of $450 \mathrm{~g} / \mathrm{heifer} / \mathrm{day}$ was maintained throughout the dormant season. The supplement was changed to a commercial mineral lick (Phossure 6, KK Animal Nutrition, South Africa) approximately two months before the beginning of the breeding season. The $\mathrm{CP}$ content of the pasture during the month prior to the onset of breeding was estimated at 7.8\% (Bransby, 1988) and the level of nitrogen in dietary intake was estimated to be low (Table 1). Only the month of birth of heifers in this herd was recorded, and a date of birth on the $15^{\text {th }}$ day of the month of birth was assigned to each heifer for analytical purposes.

Heifers in Herd B were bred by natural service in a single sire group. These heifers were managed extensively on natural pasture (CP content estimated at 6.9\%, Bransby, 1988) and a commercial production lick supplement containing 27\% CP (Summer Production lick for growth, KK Animal Nutrition, South Africa) was provided throughout the dormant season at the recommended intake of $1000 \mathrm{~g} /$ heifer/day. The supplement was changed to a higher energy lick supplement containing 18\% CP (Beef Booster 18, Meadow Animal Feeds, South 
Africa), at the recommended intake of $500 \mathrm{~g} / \mathrm{heifer} /$ day at the beginning of the breeding season. The level of dietary nitrogen intake of heifers in this herd during the month prior to breeding was estimated to be moderate (Table 1).

Table 1: Estimated levels of nitrogen intake during the month prior to breeding

\begin{tabular}{cccc}
\hline \multirow{2}{*}{ Herd } & \multicolumn{2}{c}{ Crude protein (\%) } & Dietary nitrogen intake level \\
\cline { 2 - 4 } & $\begin{array}{c}\text { From Pasture } \\
\text { (estimated) }\end{array}$ & $\begin{array}{c}\text { From the } \\
\text { supplement }\end{array}$ & \\
A & 7.8 & 0 & Low $^{\text {l }}$ \\
B & 6.9 & 23 & Moderate $^{\mathrm{m}}$ \\
C & 9.0 & 18 & Moderate $^{\text {Digh }}$ \\
D & 7.8 & 45 & Hery high $^{\text {vh }}$ \\
E & 19.5 & 18 & \\
${ }^{\mathrm{T}}=\mathrm{CP}<8 \%$ & & & \\
$\mathrm{~m}=8<\mathrm{CP}<12$ & & & \\
${ }_{\mathrm{h}}=12<\mathrm{CP}<14$ & & & \\
$\mathrm{vh}=\mathrm{CP}>14$ & &
\end{tabular}

Heifers in Herd $\mathrm{C}$ were artificially inseminated after synchronisation with progesterone impregnated intravaginal devices (CIDR Easy Breed, Pfizer Animal Health), followed by natural mating with one bull. This herd was managed semi-intensively on irrigated oat pastures (estimated to contain 9\% CP, Bransby, 1988) with an $18 \% \mathrm{CP}$ commercial production lick supplement (Production lick, Driehoek Feeds, South Africa)) during the 2 months prior to the breeding season (recommended lick intake $1000 \mathrm{~g} / \mathrm{heifer} / \mathrm{day}$ ). The level of dietary nitrogen intake in this herd during the month prior to the onset of breeding was estimated to be moderate (Table 1). At the beginning of the breeding season, heifers were moved to natural pasture where they received a commercial mineral lick supplement (Phossure 6, KK Animal Nutrition, South Africa) ad lib, intake estimated at $60-100$ g/heifer/day.

Heifers in Herd D were bred by natural service in a single sire group. The herd was managed extensively on natural pasture (CP content estimated to be $7.8 \%$, Bransby, 1988) with a $45 \%$ CP commercial protein lick supplement (Voermol Dundee lick, Voermol, South Africa) that 
was provided during the dormant season (estimated intake $450 \mathrm{~g} / \mathrm{heifer} /$ day). The total dietary nitrogen intake during the month prior to the onset of breeding was estimated to be high (Table 1). The protein supplementation was replaced with a commercial mineral lick (Phossure 6, KK Animal Nutrition, South Africa) at the beginning of the breeding season with an estimated intake of $60-100 \mathrm{~g} / \mathrm{heifer/day.}$

Heifers in Herd E were bred by natural service in multisire groups of 3 to 4 bulls per 100 heifers. They were managed semi-intensively on irrigated rye grass pastures with an estimated CP content of 19.5\% (Bransby, 1988) and supplemented with an 18\% CP energy lick (Produksielek 180, Saamstaan Feeds Vrede, South Africa) that was specifically made for this farm starting five months prior to the onset of the breeding season. The recommended intake for this lick was $1000 \mathrm{~g} / \mathrm{heifer} / \mathrm{day}$. The total dietary nitrogen intake during the month prior to the onset of breeding was estimated to be very high (Table 1). Heifers were moved to natural pasture (over sown with Themeda triandra) on the first day of the breeding season and provided with a commercial mineral lick (Phossure, KK Animal Nutrition, South Africa) at the recommended intake of $100 \mathrm{~g} /$ heifer/day. Sampling in Herd E was performed over two consecutive days.

\section{Study design and data collection}

The sample size was estimated based on the normal approximation to the binomial for the comparison of two proportions assuming equal group sizes at a power of $80 \%$ and an allowable alpha error of 5\%. It was assumed that animals with higher levels of BUN would have a pregnancy proportion of $85 \%$ compared to other heifers in which the proportion was expected to be $95 \%$ based on the industry standard of a $90 \%$ pregnancy proportion. The sample size was calculated as 160 heifers per group and increased by $10 \%$ (352 total) to account for losses during follow-up (Fosgate, 2009). 
Data were collected during two farm visits, the first being within one week prior to the commencement of the breeding season during which blood samples, age, body mass, body condition score (BCS) and reproductive tract score (RTS) data were collected. A second visit was conducted four to eight weeks after the termination of the breeding season for pregnancy testing.

Heifers were restrained in a crush and blood samples were collected by venepuncture from the coccygeal vein or artery into evacuated $4 \mathrm{ml}$ serum tubes (Becton Dickinson, BD vacutainer CAT, silicone clot activator). Blood samples were centrifuged at $4000 \mathrm{rpm}$ for 8 minutes immediately after clot formation, separated into micro centrifuge tubes $(2 \mathrm{ml})$ and frozen in a portable freezer at $-18^{\circ} \mathrm{C}$. After blood sampling, BCS and RTS were performed and recorded on scales from 1 to 9 and 1 to 5 respectively according to standardised protocols (Andersen et al., 1991, Marston et al., 2005). Frozen serum samples were delivered to the clinical pathology laboratory at the Faculty of Veterinary Science of the University of Pretoria within two days of sampling. Serum was stored at $-80{ }^{\circ} \mathrm{C}$ for a maximum of 30 days prior to testing using an auto analyser machine (Cobas Integra 400 plus, Roche, Switzerland). Pregnancy status and foetal age (in days) was determined by a single investigator (TT), either by transrectal palpation, or transrectal ultrasonography if the stage of pregnancy was judged to be less than 56 days by palpation (Sheldon and Noakes, 2002; Romano et al., 2006; Youngquist, 2007). Ultrasonography was performed using a portable ultrasound machine with a 3.5 - $5 \mathrm{MHz}$ linear transducer (CTS900V, Shantou Institute for Ultrasonic Instruments, China). Records of the days that heifers were observed to be mated, when available, were used to verify accuracy of the estimated foetal age. Days to pregnancy (DTP) was calculated as the total number of days from the start of the breeding season to pregnancy examination minus the estimated foetal age. 
Informed consent was obtained from all herd owners prior to sampling and typical farming practices continued throughout the study. Farmers were not informed of the BUN, BCS, and RTS data prior to pregnancy testing.

\section{Statistical analysis}

Data normality was assessed by plotting histograms, calculating descriptive statistics, and performing the Anderson-Darling test. Data satisfying the normality assumption were presented as mean $+/$ - standard deviation $(\mathrm{SD})$ and non-normal data were presented as the median and range (minimum, maximum).

Conditional logistic regression analysis was performed to measure the association between BUN concentration and subsequent pregnancy while adjusting for herd as the grouping factor and other potential confounders by including main effect terms in the models. Variables that caused $15 \%$ or greater change in the odds ratio (OR) for BUN concentration when included in models were considered important confounders.

Stratified Cox proportional hazards analysis was performed to investigate the effect of BUN concentration on DTP. Heifers that did not become pregnant were right censored, and those that were lost to follow up were excluded from the analysis. Herd was included as the stratifying factor and other potential confounders were evaluated as main effects. Sampling day was forced into all models in herds where sampling required two days.

Reproductive tract score and BCS were screened as ordinal variables and dichotomized when significant associations $(P<0.2)$ with BUN were identified. Categorisation was performed based on the relative frequencies within each category. Specifically, RTS was grouped as 1 to 3 versus 4 and 5. Results for the ordinal coding were reported when categorisation did not suggest violation of the assumption of being linear in the natural logarithm on the odds or 
hazard scale. In addition to confounding variables, all variables with $P<0.2$ were entered into all multivariable models and removed one by one in a backward elimination process based on the largest Wald $P$ values until only variables that were significantly associated with the outcome remained $(P<0.05)$.

Data were analysed using commercially available software (IBM SPSS Statistics Version 20, International Business Machines Corp., Armonk, NY, USA; MINITAB Statistical Software, Release 13.32, Minitab Inc., State College, Pennsylvania, USA).

$P$-values less than 0.05 were defined as being significant, values between 0.05 and 0.1 as borderline significant and values greater than 0.1 as being not significant.

\section{Results}

Three hundred and sixty-nine heifers were sampled at the start of the study and 338 were present at the time of pregnancy examination. The overall age at breeding varied from 12 to 31 months (Table 2 ). The mean body mass and BUN concentration ( \pm SD) was $283 \mathrm{~kg} \pm 48$ and $5.27 \mathrm{mmolL}^{-1} \pm 1.8$ respectively. Heifers were generally in good condition (BCS $\geq 3$ ) and there were no marked differences in BCS within and between herds. Pregnancy proportion varied from $41 \%$ to $100 \%$ and the median DTP (min, max) was $40(4,89)$.

The association between BUN concentration and pregnancy status overall was borderline significant $(P=0.068)$ and was significant in Herds D and E (Table 3). Heifers with a higher BUN concentration at the beginning of the breeding season in Herd D $(\mathrm{OR}=0.478 ; 95 \% \mathrm{CI}$ : $0.232-0.987)$ and $\mathrm{E}(\mathrm{OR}=0.617 ; 95 \% \mathrm{CI}: 0.422-0.903)$ had lower odds of becoming pregnant. It was not possible to perform logistic regression for Herds B and C because they had pregnancy proportions of $100 \%$. Heifers with higher BUN concentration had a lower rate of becoming pregnant $(\mathrm{HR}=0.832 ; 95 \% \mathrm{CI}: 0.722-0.958, P=0.011)$ (Table 4$)$. 
Table 2: Descriptive statistics for all herds

\begin{tabular}{|c|c|c|c|c|c|c|c|c|}
\hline Herd & n & $\begin{array}{c}\text { Age } \\
\text { (range) }\end{array}$ & $\begin{array}{l}\text { Mass } \\
\pm \text { SD }\end{array}$ & $\begin{array}{l}\text { BUN } \\
\pm \text { SD }\end{array}$ & $\begin{array}{c}\text { BCS } \\
\text { (range) }\end{array}$ & $\begin{array}{c}\text { RTS } \\
\text { (range) }\end{array}$ & $\begin{array}{c}\text { DTP } \\
\text { (range) }\end{array}$ & $\begin{array}{l}\text { PP } \\
(\%)\end{array}$ \\
\hline Overall & 338 & $\begin{array}{c}19 \\
(12,31)\end{array}$ & $283 \pm 48$ & $5.27 \pm 1.80$ & $\begin{array}{c}5 \\
(3,7)\end{array}$ & $\begin{array}{c}4 \\
(1,5)\end{array}$ & $\begin{array}{c}40 \\
(4,89)\end{array}$ & 63 \\
\hline $\mathbf{A}$ & 106 & $\begin{array}{c}19 \\
(14,24)^{*}\end{array}$ & - & $5.37 \pm 0.81$ & $\begin{array}{c}5 \\
(4,5)\end{array}$ & $\begin{array}{c}4 \\
(2,5)\end{array}$ & $\begin{array}{c}43 \\
(15,89)\end{array}$ & 71 \\
\hline B & 33 & $\begin{array}{c}25 \\
(20,26)\end{array}$ & $318 \pm 32$ & $2.20 \pm 0.67$ & $\begin{array}{c}5 \\
(3,5)\end{array}$ & $\begin{array}{c}3 \\
(1,5)\end{array}$ & $\begin{array}{c}24 \\
(10,59)\end{array}$ & 100 \\
\hline C & 34 & $\begin{array}{c}26 \\
(24,27)\end{array}$ & $297 \pm 29$ & $4.14 \pm 0.92$ & $\begin{array}{c}6 \\
(5,7)\end{array}$ & $\begin{array}{c}5 \\
(3,5)\end{array}$ & $\begin{array}{c}4 \\
(4,81)\end{array}$ & 100 \\
\hline D & 22 & $\begin{array}{c}24 \\
(22,31)\end{array}$ & $380 \pm 38$ & $4.50 \pm 1.80$ & $\begin{array}{c}5 \\
(4,6)\end{array}$ & $\begin{array}{c}4 \\
(1,5)\end{array}$ & $\begin{array}{c}47 \\
(12,75)\end{array}$ & 68 \\
\hline $\mathbf{E}_{1}$ & 80 & $\begin{array}{c}14 \\
(12,23)\end{array}$ & $256 \pm 26$ & $7.40 \pm 1.14$ & $\begin{array}{c}5 \\
(4,6)\end{array}$ & $\begin{array}{c}4 \\
(3,5)\end{array}$ & $\begin{array}{c}40 \\
(12,89)\end{array}$ & 54 \\
\hline $\mathbf{E}_{2}$ & 63 & $\begin{array}{c}14 \\
(12,22)\end{array}$ & $257 \pm 28$ & $4.77 \pm 1.16$ & $\begin{array}{c}5 \\
(4,6)\end{array}$ & $\begin{array}{c}4 \\
(1,5)\end{array}$ & $\begin{array}{c}47 \\
(12,89)\end{array}$ & 41 \\
\hline
\end{tabular}

*The exact ages of individual animals in this herd were not known. Only the month of birth was available Age $=$ median age in months

BCS $=$ Median body condition score

BUN $=$ Mean blood urea nitrogen concentration in $\mathrm{mmolL}^{-1}$

DTP = Median days to pregnancy

$\mathrm{E}_{1}=$ first day of sampling in Herd $\mathrm{E}$

$\mathrm{E}_{2}=$ second day of sampling in Herd E

Mass $=$ mass of the heifers in kilograms

$\mathrm{n}=$ sample size

$\mathrm{PP}=$ Pregnancy proportion

RTS $=$ Median reproductive tract score

$\mathrm{SD}=$ Standard deviation 
Table 3: Association between pre-breeding BUN concentration and pregnancy status

\begin{tabular}{|c|c|c|c|c|c|c|}
\hline \multirow[b]{4}{*}{ Herd } & \multirow[b]{4}{*}{$\mathbf{n}$} & \multirow[b]{4}{*}{$\mathbf{B U N} \pm \mathbf{S D}$} & \multicolumn{4}{|c|}{$\begin{array}{c}\text { Association between BUN } \\
\text { concentration and Pregnancy status }\end{array}$} \\
\hline & & & \multirow{3}{*}{ OR } & \multicolumn{2}{|c|}{$95 \% \mathrm{CI}$ of OR } & \multirow{3}{*}{$\begin{array}{l}P \text { - } \\
\text { value }\end{array}$} \\
\hline & & & & & & \\
\hline & & & & Lower & Upper & \\
\hline Overall & 338 & $5.27 \pm 1.80$ & $0.881^{\mathrm{a}}$ & 0.768 & 1.009 & 0.068 \\
\hline $\mathbf{A}$ & 106 & $5.37 \pm 0.81$ & $0.833^{\mathrm{u}}$ & 0.460 & 1.511 & 0.548 \\
\hline B & 33 & $2.20 \pm 0.67$ & N.A & N.A & N.A & N.A \\
\hline $\mathbf{C}$ & 34 & $4.14 \pm 0.92$ & N.A & N.A & N.A & N.A \\
\hline D & 22 & $4.50 \pm 1.80$ & $0.478^{\mathrm{u}}$ & 0.232 & 0.987 & 0.046 \\
\hline $\mathbf{E}$ & 143 & $6.09 \pm 1.15$ & $0.617^{\mathrm{ms}}$ & 0.422 & 0.903 & 0.013 \\
\hline
\end{tabular}

${ }^{\mathrm{a}}=$ adjusted for age

$\mathrm{BUN} \pm \mathrm{SD}=$ mean $\mathrm{BUN}$ concentration in $\mathrm{mmolL}^{-1} \pm$ standard deviation

$\mathrm{CI}=$ confidence interval

$\mathrm{n}=$ sample size

N.A = not applicable

${ }^{\mathrm{ms}}=$ adjusted for mass and sample day

${ }^{\mathrm{u}}=$ unadjusted 


\begin{tabular}{|c|c|c|c|c|c|c|c|}
\hline \multirow[b]{3}{*}{ Herd } & \multirow[b]{3}{*}{$\mathbf{n}$} & \multirow{3}{*}{$\begin{array}{c}\text { Dietary } \\
\text { Nitrogen } \\
\text { intake level }\end{array}$} & \multirow[b]{3}{*}{$\mathbf{B U N} \pm \mathbf{S D}$} & \multicolumn{4}{|c|}{$\begin{array}{l}\text { Association between BUN } \\
\text { concentration and DTP }\end{array}$} \\
\hline & & & & \multirow[t]{2}{*}{ HR } & $95 \% \mathrm{CI}$ & $\mathrm{fHR}$ & \multirow[t]{2}{*}{$\begin{array}{l}P \text { - } \\
\text { value }\end{array}$} \\
\hline & & & & & Lower & Upper & \\
\hline Overall & 338 & & $5.27 \pm 1.80$ & $0.832^{\mathrm{a}}$ & 0.722 & 0.958 & 0.011 \\
\hline $\mathbf{A}$ & 106 & Low & $5.37 \pm 0.81$ & $0.969^{\mathrm{u}}$ & 0.737 & 1.276 & 0.824 \\
\hline $\mathbf{B}$ & 33 & Moderate & $2.20 \pm 0.67$ & $1.113^{\mathrm{p}}$ & 0.644 & 1.926 & 0.701 \\
\hline $\mathbf{C}$ & 34 & Moderate & $4.14 \pm 0.92$ & $0.997^{\mathrm{p}}$ & 0.647 & 1.535 & 0.989 \\
\hline D & 22 & High & $4.50 \pm 1.80$ & $0.799^{r}$ & 0.564 & 1.132 & 0.207 \\
\hline $\mathbf{E}$ & 143 & Very high & $6.09 \pm 1.15$ & $0.748^{\mathrm{ms}}$ & 0.589 & 0.950 & 0.017 \\
\hline $\begin{array}{l}\text { sted for ag } \\
\text { SD = meal } \\
\text { fidence in } \\
\text { Days to pre } \\
\text { usted for } \mathrm{n} \\
\text { ple size } \\
\text { justed } \\
\text { iple regres } \\
\text { ted for RT }\end{array}$ & $\begin{array}{l}\text { lood } \\
\text { val } \\
\text { ancy } \\
\text { and }\end{array}$ & $\begin{array}{l}\text { a nitrogen co } \\
\text { apling day } \\
\text { sible }\end{array}$ & ation in 1 & ${ }^{1} \pm$ the & $\operatorname{ard} d \epsilon$ & ion & \\
\hline
\end{tabular}

\section{Discussion}

Heifers in this study were raised under typical South African commercial beef cow-calf enterprise conditions, where researchers had no control over farming practices such as the sale of animals, provision of dietary supplements and the use of reproductive technologies (synchronisation and artificial insemination). Despite this lack of control, results from this study have an important practical application because they were obtained from commercially 
viable operations. Although many other variables are associated with pregnancy outcome (Chenoweth, 2005), these variables were not evaluated during the study. An assumption was made that such differences would be herd-level effects that could be adjusted by including herd in the statistical models to account for unmeasured variables. Herd, was forced into all models as a stratifying factor and other potential confounders were evaluated as main effects. To the knowledge of the authors, none of these, except energy, have a direct interaction with BUN in determining the pregnancy outcome.

BUN concentration was only determined once prior to the onset of the breeding season. However, it is likely that BUN concentration in the heifers continued to vary during the breeding season due to dietary and environmental changes. Nevertheless, since the environmental changes are likely to have affected all heifers in the herd in a similar way, and that urea concentration is genetically determined, it was assumed that those heifers that initially had a higher BUN concentration remained high relative to the rest of the herd throughout the breeding season. To the knowledge of the authors this hypothesis has not been previously tested. Since all the heifers in each herd were sampled on the same day under similar conditions (except for Herd E), it was therefore assumed that the measured BUN concentration reflects the distribution of relative BUN concentration in that herd. Since Herd E was sampled over 2 days, it was therefore necessary to force sampling day into all regression models to account for potential confounding.

The pregnancy proportion for Herds A, D and E was lower than the benchmark for beef cowcalf operations (> 90\% pregnancy rate) with a 62-day breeding season (Chenoweth and Sanderson, 2001). The reason for the lower pregnancy proportion in Herds A and E is not clear, but is thought to be due to heifers in these herds being immature at the onset of the breeding season and probably not cycling. The long DTP in these herds strengthens the suspicion of immaturity at the onset of the breeding season. This is in agreement with the 
work done by other researchers that have reported that heifers that mature fast and undergo a few complete oestrous cycles before the breeding season tend to have better reproductive performance (Yelich et al., 1996; Berry et al., 2003).

The $100 \%$ pregnancy proportion and relatively low DTP in Herds B and C was likely due to the heifers being mature and cycling prior to the onset of the breeding season. However it is important to note that Herd $\mathrm{C}$ utilized oestrus synchronisation and artificial insemination and these procedures are known to improve pregnancy proportion and reduce DTP (Xu and Burton, 1999).

Most authors advocate the use of pregnancy proportion and days to calving (DTC) as the most appropriate measures of reproductive performance (Meyer et al., 1990; MacGregor and Casey, 1999; Eler et al., 2002). In this study, DTP was used instead of DTC in order to exclude abortions and variations in gestational length, which are not expected to be related to BUN concentration.

It is the authors' opinion that in a restricted breeding season, DTP will be a better measure of reproductive performance than pregnancy proportion because if the breeding season had been long enough, most heifers would eventually become pregnant and pregnancy proportion alone would not differentiate heifers with good reproductive performance from those with poor performance.

Assuming that cycling occurs randomly in heifers, except in herds where oestrous synchronisation is practised, stage of the oestrous cycle when the breeding season commenced would have affected DTP in individual animals. Stage of the oestrous cycle at the onset of breeding was not known, however, because of the relatively large sample size, it was assumed that this imprecision (random error) did not negate the usefulness of DTP. 
Pre-breeding BUN concentration was significantly associated with DTP but not pregnancy status in all herds combined. This suggests that high BUN concentration before the onset of the breeding season negatively affected the chances of becoming pregnant only early during the breeding season and that this effect was lost as the breeding season progressed. The first possible explanation is that some animals adapted to the increased BUN concentration as suggested by Calsamiglia et al. (2010). Alternatively, BUN levels may have decreased during the course of the breeding season due to dietary changes. The latter option is highly possible because rumen degradable protein supplementation was stopped in all herds at the beginning of the breeding season. The results of this study are similar to those of Guo et al. (2004), who showed that in among-herd analyses; MUN concentration had minimal effect on conception rate but was associated with greater days open. Ferguson et al. (1993) also showed that within dairy herds with mean MUN concentrations above $20 \mathrm{mg} / \mathrm{dL}$, cows with higher MUN levels were associated with poorer conception at first service, but not at subsequent services. The short duration of the negative effects of high BUN concentration in these studies was probably due to the fact that dairy cows are usually bred for the first time while they are still adapting to lactational rations and experiencing high BUN concentrations (Jorritsma et al., 2003).

It is thought that in dairy cattle, the negative effect of high BUN concentration might be exerted through the exacerbation of an underlying negative energy balance (NEB) and the energy costs of detoxifying large quantities of ammonia in post-partal cattle (Staples et al., 1990; Garcia-Bojalil et al., 1998; Overton et al., 1999). However, it can be assumed that beef heifers will not suffer from NEB as is the case in lactating dairy cattle. In this study, BCS was used as an indicator of the animal's energy reserves. This is widely supported in literature for both beef and dairy cattle (Wildman et al., 1982; Edmonson et al., 1989; Houghton et al., 1990). However, BCS has been shown to have lower accuracy in young growing cows 
because growing animals tend to have less fat deposits (Nicholson and Butterworth, 1986). The heifers in this study were at an optimum BCS (median $=5$ ) with little variation within and between herds. The lack of variation made it impossible to estimate the effect of BCS on reproductive performance.

Variation in the genetic ability to utilise nitrogen has been well documented (Mitchell et al., 2005; Bouwman et al., 2010; Hossein-Zadeh and Ardalan, 2011). It has been shown in dairy cattle that animals with better nitrogen retaining abilities have lower BUN levels (Nousiainen et al., 2004). However in an earlier review, Schoeman (1989) concluded that beef cattle with better nitrogen utilising abilities had higher BUN levels. Although the exact reason for the apparent lack of agreement in their conclusions is not known, it is hypothesised that the relationship between BUN concentration and nitrogen retention in beef cattle that are on natural grazing may be the opposite of what happens in dairy cattle due to the relatively lower dietary nitrogen intake. This would be due to more efficient recirculation of nitrogen during times of reduced dietary nitrogen intakes. The relationship of BUN and nitrogen utilisation efficiency in beef cattle under different levels of nitrogen intake needs further investigation.

Feeding high levels of rumen degradable protein (RDP) is known to down-regulate the efficiency of nitrogen recirculation (Marini and van Amburgh, 2003; Marini et al., 2004), leading to higher BUN concentration and renal loss. If the above hypothesis is correct, then beef heifers with better abilities to retain nitrogen within herds that were supplied with potentially excessive levels of RDP might have lost their advantage and suffered more negative consequences from the effects of high BUN concentrations. This suggests that heifers with an improved ability to retain nitrogen within herds heavily supplemented with RDP (in order to achieve faster growth) are at risk of being culled for poor fertility in a restricted breeding system. 


\section{Conclusion}

Blood urea nitrogen concentration prior to the start of breeding was independently associated with reproductive performance of Bonsmara heifers, especially in herds where management included supplementation of dietary nitrogen to achieve early breeding.

It is recommended that production systems designed to achieve early breeding in beef heifers investigate whether oversupplying rumen degradable protein selects against animals with relatively high levels of blood urea nitrogen.

\section{Acknowledgements}

The authors thank the participating farmers for providing the animals, facilities and farm records, and the Faculty of Veterinary Science, University of Pretoria for financial support. This research was performed under protocol number V072-810 as approved by the Animal Ethics Committee of the University of Pretoria.

\section{Conflict of Interest}

Any opinion, finding and conclusion or recommendation is that of the authors. There were no conflict of interests

\section{References}

Andersen, K.J., LeFever, D.G., Brinks, J.S. and Odde, K.G., 1991. The use of reproductive tract scoring system in beef heifers, Agri-Practice, 12, 19-26

Berry, D.P., Buckley, F., Dillon, P., Evans, R.D., Rath, M. and Veerkamp, R.F., 2003. Genetic Relationships among Body Condition Score, Body Weight, Milk Yield, and Fertility in Dairy Cows, Journal of dairy science, 86, 2193-2204 
Bierman, S., Erickson, G.E., Klopfenstein, T.J., Stock, R.A. and Shain, D.H., 1999. Evaluation of nitrogen and organic matter balance in the feedlot as affected by level and source of dietary fiber., Journal of animal science, 77, 1645-1653

Bouwman, A.C., Schopen, G.C.B., Bovenhuis, H., Visker, M.H.P.W. and van Arendonk, J.A.M., 2010. Genome-wide scan to detect quantitative trait loci for milk urea nitrogen in Dutch Holstein-Friesian cows, Journal of dairy science, 93, 3310-3319

Bransby, D.I., 1988. The Value of Veld and Pasture as an Animal Feed. In: N.M. Tainton(ed), Veld and Pasture Management in South Africa, (Shuter \& Shooter in association with University of Natal Press, Pietermaritzburg), 175-214

Britt, J.H., 2008. Oocyte development in cattle: physiological and genetic aspects, Revista Brasileira de Zootecnia, 37, 110-115

Calsamiglia, S., Ferret, A., Reynolds, C.K., Kristensen, N.B. and Vuuren, A.M.v., 2010. Strategies for optimizing nitrogen use by ruminants., Animal, 4, 1184-1196

Carlsson, J. and Pehrson, B., 1993. The Relationships Between Seasonal Variations in the Concentration of Urea in Bulk Milk and the Production and Fertility of Dairy Herds, Journal of Veterinary Medicine Series A, 40, 205-212

Chase Jr., C.C., Larsen, R.E., Hammond, A.C. and Randel, R.D., 1993. Effect of dietary energy on growth and reproductive characteristics of Angus and Senepol bulls during summer in Florida, Theriogenology, 40, 43-61

Chenoweth, P.J. and Sanderson, M.W., 2001. Health and Production Management in Beef Cattle Breeding Herds. In: L.L. Duncan(ed), Herd Health Food Animal Production Medicine, (W.B. Saunders Company, New York, London), 530-531 
Chenoweth, P.J., 2005. Cow-Calf Production Principles. In: P.J. Chenoweth and M.W. Sanderson (eds), Beef Practice: Cow-calf production medicine, (Blackwell Publishing, Amos, Iowa), 9-27

Dijkstra, J., Oenema, O. and Bannink, A., 2011. Dietary strategies to reducing N excretion from cattle: implications for methane emissions, Current Opinion in Environmental Sustainability, 3, 414-422

Edmonson, A.J., Lean, I.J., Weaver, L.D., Farver, T. and Webster, G., 1989. A Body Condition Scoring Chart for Holstein Dairy Cows, Journal of dairy science, 72, 68-78

Eler, J.P., Silva, J.A.I.I.V., Ferraz, J.B.S., Dias, F., Oliveira, H.N., Evans, J.L. and Golden, B.L., 2002. Genetic evaluation of the probability of pregnancy at 14 months for Nellore heifers., Journal of animal science, 80, 951-954

Elrod, C.C. and Butler, W.R., 1993. Reduction of fertility and alteration of uterine pH in heifers fed excess ruminally degradable protein, Journal of animal science, 71, 694-701

Erickson, G. and Klopfenstein, T., 2010. Nutritional and management methods to decrease nitrogen losses from beef feedlots, Journal of animal science, 88, E172-E180

Ferguson, J.D., Galligan, D.T., Blanchard, T. and Reeves, M., 1993. Serum Urea Nitrogen and Conception Rate: The Usefulness of Test Information, Journal of dairy science, 76, $3742-3746$

Fosgate, G.T., 2009. Practical Sample Size Calculations for Surveillance and Diagnostic Investigations, Journal of Veterinary Diagnostic Investigation, 21, 3-14 
Garcia-Bojalil, C.M., Staples, C.R., Risco, C.A., Savio, J.D. and Thatcher, W.W., 1998. Protein Degradability and Calcium Salts of Long-Chain Fatty Acids in the Diets of Lactating Dairy Cows: Productive Responses, Journal of dairy science, 81, 1374-1384

Godden, S.M., Lissemore, K.D., Kelton, D.F., Leslie, K.E., Walton, J.S. and Lumsden, J.H., 2001. Factors Associated with Milk Urea Concentrations in Ontario Dairy Cows, Journal of dairy science, $84,107-114$

Guo, K., Russek-Cohen, E., A.Varner, M. and Kohn, R.A., 2004. Effects of Milk Urea Nitrogen and Other Factors on Probability of Conception of Dairy Cows, Journal of dairy science, $87,1878-1885$

Hossein-Zadeh, N.G. and Ardalan, M., 2011. Estimation of genetic parameters for milk urea nitrogen and its relationship with milk constituents in Iranian Holsteins, Livestock Science, 135, 274-281

Houghton, P.L., Lemenager, R.P., Moss, G.E. and Hendrix, K.S., 1990. Prediction of Postpartum Beef Cow Body Composition Using Weight to Height Ratio and Visual Body Condition Score., Journal of animal science, 68, 1428-1437

Irons, P.C., Nöthling, J.O. and Bertschinger, H.J., 2007. Bull breeding soundness evaluation in Southern Africa, Theriogenology, 68, 842-847

Jorritsma, R., Wensing, T., Theo, A.M.K., Peter, L.A.M.V. and Jos, P.T.M.N., 2003. Metabolic changes in early lactation and impaired reproductive performance in dairy cows, Vet.Res., 34, 11-26 
Kauffman, A.J. and St-Pierre, N.R., 2001. The Relationship of Milk Urea Nitrogen to Urine Nitrogen Excretion in Holstein and Jersey Cows, Journal of dairy science, 84, 22842294

Kohn, R.A., Dinneen, M.M. and Russek-Cohen, E., 2005. Using blood urea nitrogen to predict nitrogen excretion and efficiency of nitrogen utilization in cattle, sheep, goats, horses, pigs, and rats, Journal of animal science, 83, 879-889

MacGregor, R.G. and Casey, N.H., 1999. Evaluation of calving interval and calving date as measures of reproductive performance in a beef herd, Livestock Production Science, $57,181-191$

Marini, J.C., Klein, J.D., Sands, J.M. and van Amburgh, M.E., 2004. Effect of nitrogen intake on nitrogen recycling and urea transporter abundance in lambs., Journal of animal science, $82,1157-1164$

Marini, J.C. and van Amburgh, M.E., 2003. Nitrogen metabolism and recycling in Holstein heifers, Journal of animal science, 81, 545-552

Marston, T. T. 2005. Beef cowherd nutrition and management. In: Chenoweth, P. J., M. W. Sanderson (Eds). Beef practice; Cow-calf production medicine: 89 - 108 Blackwell Publishing, Ames, Iowa.

Meyer, K., Hammond, K., Parnell, P.F., MacKinnon, M.J. and Sivarajasingam, S., 1990. Estimates of heritability and repeatability for reproductive traits in Australian beef cattle., Livestock Production Science, 25, 15-30

Mitchell, R.G., Rogers, G.W., Dechow, C.D., Vallimont, J.E., Cooper, J.B., Sander-Nielsen, U. and Clay, J.S., 2005. Milk Urea Nitrogen Concentration: Heritability and Genetic 
Correlations with Reproductive Performance and Disease, Journal of dairy science, 88 , $4434-4440$

Muscher, A.S., Schröder, B., Breves, G. and Huber, K., 2010. Dietary nitrogen reduction enhances urea transport across goat rumen epithelium, Journal of animal science, 88 , 3390-3398

Ndlovu, T., Chimonyo, M., Okoh, A.I., Muchenje, V., Dzama, K. and Raats, J.G., 2007. Assessing the nutritional status of beef cattle: current practices and future prospects, African Journal of Biotechnology, 6, 2727-2734

Nicholson, M.J. and Butterworth, M.H., 1986. A Guide to Condition Scoring of Zebu Cattle, (International Livestock Centre for Africa, Addis Ababa, Ethiopia)

Nousiainen, J., Shingfield, K.J. and Huhtanen, P., 2004. Evaluation of Milk Urea Nitrogen as a Diagnostic of Protein Feeding, Journal of dairy science, 87, 386-398

Overton, T.R., Drackley, J.K., Ottemann-Abbamonte, C.J., Beaulieu, A.D., Emmert, L.S. and Clark, J.H., 1999. Substrate utilization for hepatic gluconeogenesis is altered by increased glucose demand in ruminants., Journal of animal science, 77, 1940-1951

Rajala-Schultz, P.J. and Saville, W.J.A., 2003. Sources of Variation in Milk Urea Nitrogen in Ohio Dairy Herds, Journal of dairy science, 86, 1653-1661

Romano, J.E., Thompson, J.A., Forrest, D.W., Westhusin, M.E., Tomaszweski, M.A. and Kraemer, D.C., 2006. Early pregnancy diagnosis by transrectal ultrasonography in dairy cattle, Theriogenology, 66, 1034-1041 
Schoeman, S.J., 1989. Recent research into the production potential of indigenous cattle with special reference to the Sanga, South African Journal of Animal Science, 19, 55-61

Sheldon, M. and Noakes, D., 2002. Pregnancy diagnosis in cattle, In practice, 24, 310-317

Staples, C.R., Thatcher, W.W. and Clark, J.H., 1990. Relationship Between Ovarian Activity and Energy Status During the Early Postpartum Period of High Producing Dairy Cows1,2, Journal of dairy science, 73, 938-947

Stoop, W.M., Bovenhuis, H. and van Arendonk, J.A.M., 2007. Genetic Parameters for Milk Urea Nitrogen in Relation to Milk Production Traits, Journal of dairy science, 90, 19811986

Wildman, E.E., Jones, G.M., Wagner, P.E., Boman, R.L., Troutt Jr., H.F. and Lesch, T.N., 1982. A Dairy Cow Body Condition Scoring System and Its Relationship to Selected Production Characteristics, Journal of dairy science, 65, 495-501

Xu, Z.Z. and Burton, L.J., 1999. Effects of oestrus synchronisation and fixed-time artificial insemination on the reproductive performance of dairy heifers, New Zealand veterinary journal, 47, 101-104

Yelich, J.V., Wettemann, R.P., Marston, T.T. and Spicer, L.J., 1996. Luteinizing hormone, growth hormone, insulin-like growth factor-I, insulin and metabolites before puberty in heifers fed to gain at two rates, Domestic animal endocrinology JID - 8505191, 13, $325-328$

Youngquist, R.S., 2007. Pregnancy Diagnosis. In: Anonymous Current Therapy in Large Animal Theriogenology (Second Edition), (W.B. Saunders, Saint Louis), 294-303 